\title{
FAKTOR-FAKTOR YANG BERPENGARUH TERHADAP HARGA SAHAM SYARIAH PT. WIJAYA KARYA, TBK., DAN PT. ANEKA TAMBANG, TBK.
}

\author{
Zahida I'tisoma Billah \\ Manajemen Keuangan Syariah, Universitas Islam Zainul Hasan Genggong Probolinggo \\ zahidafe@gmail.com \\ Nuri Fara Daisil Jinnani \\ Manajemen Keuangan Syariah, Universitas Islam Zainul Hasan Genggong Probolinggo \\ nurifaradj@gmail.com
}

\begin{abstract}
The stock price always changes. Investors can find out the factors that influence it with a fundamental analysis of the company's financial statements. This study aims to determine whether the Return On Assets, Return On Equity, and Debt to Equity Ratio affect the stock price fluctuation of PT. Wijaya Karya, Tbk. and PT. Aneka Tambang, Tbk. in 2016-2018. The research method used is descriptive quantitative, then this study uses the population and samples in the selection of research objects. The population consisted of 30 companies registered in JII, the sampling method was purposive sampling and obtained PT. Wijaya Karya, Tbk. and PT. Aneka Tambang, Tbk. The research data is secondary data obtained from the annual financial reports of the two research samples. The data analysis technique used is multiple regression. The results of the study concluded that both simultaneously and partially $\mathrm{ROA}, \mathrm{ROE}$, and DER did not have a significant effect on the stock. price of PT. Wijaya Karya, Tbk. and PT. Aneka Tambang, Tbk. 2016-2018 period.
\end{abstract}

Keywords: ROA, ROE, DER, Stock Price

\begin{abstract}
Abstrak
Harga saham selalu mengalami perubahan. Investor dapat mengetahui faktor-faktor yang mempengaruhinya dengan analisis fundamental dari laporan keuangan perusahaan. Penelitian ini bertujuan untuk mengetahui apakah Return On Assets (ROA), Return On Equity (ROE), dan Debt to Equity Ratio (DER) mempengaruhi fluktuasi harga saham PT. Wijaya Karya, Tbk. dan PT. Aneka Tambang, Tbk. pada tahun 2016-2018. Metode penelitian yang digunakan adalah deksriptif kuantitatif, kemudian penelitian ini menggunakan populasi dan sampel dalam pemilihan objek penelitiannya. Populasi terdiri dari 30 perusahaan yang terdaftar di JII, metode pengambilan sampel dengan purposive sampel, dan didapatkan PT. Wijaya Karya, Tbk. dan PT. Aneka Tambang, Tbk. Data penelitian merupakan data sekunder yang diperoleh dari laporan keuangan tahunan kedua sampel penelitian. Teknik analisis data yang digunakan ialah regresi berganda. Hasil penelitian menyimpulkan bahwa baik secara simultan dan parsial ROA, ROE, dan DER tidak memberikan pengaruh signifikan terhadap harga saham PT. Wijaya Karya, Tbk. dan PT. Aneka Tambang, Tbk. periode 2016-2018.
\end{abstract}

Kata kunci: ROA, ROE, DER, Harga Saham 


\section{Pendahuluan}

Investasi merupakan salah satu kegiatan yang bertujuan untuk mengembangkan harta kekayaan dengan cara memberikan modal atau menanamkan modalnya kepada perusahaan yang akan ditanamkan modal. Penanaman modal tersebut berupa saham, saham disini dapat diartikan sebagai surat atau bukti tanda kepemilikan suatu perusahaan. Dalam berinvestasi khususnya penanaman modal pada perusahaan, tidak semua aktivitas atau kinerja perusahaan sesuai dengan keinginan atau prospek ke depan yang baik, oleh karena itu para investor tidak selalu mendapatkan keuntungan dari investasinya melainkan juga bisa mendapatkan resiko kerugian dari investasi tersebut.

Investor dikatakan mengalami resiko jika harga saham yang dibelinya mengalami penurunan dan saham yang dijual pada saat harga jualnya lebih rendah dari pada harga beli, begitu juga sebaliknya para investor akan mengalami keuntungan jika harga saham naik, maka dapat diketahui bahwa perusahaan yang sudah diinvestasikan tersebut akan memberikan keuntungan yang berupa deviden dan capital gain dari perusahaan tersebut.

Selain memperoleh dividen dan capital gain, dengan kepemilikan saham sebuah perusahaan investor memiliki kelebihan lainnya yaitu memiliki suara dalam Rapat Umum Pemegang Saham (RUPS). Seperti yang diketahui harga saham suatu emiten dapat berubah-ubah setiap harinya. Banyak faktor yang mempengaruhi, Fahmi (2015) menyebutkan terdapat beberapa kondisi dan situasi naik dan turunnya harga saham suatu perusahaan, baik dari faktor mikro maupun makro. Faktor mikro seperti, kinerja keuangan perusahaan, kebijakan ekspansi perusahaan, pergantian dewan direksi, kasus pidana dalam perusahaan, dan risiko sistematis yang ada pada perusahaan. Sedangkan faktor makro, berupa keadaan ekonomi Indonesia dan faktor politik Indonesia (Fahmi, 2015).

Resiko dan keuntungan oleh investor dipengaruhi oleh beberapa faktor, seperti menurunnya kualitas kinerja perusahaan atau bertambahnya hutang operasional perusahaan, oleh karena itu para investor harus bisa menganalisis saham suatu perusahaan agar resiko dapat diminimalisirkan. Analisis dapat dilakukan dengan memperhatikan aspek fundamental dan teknikal dari saham suatu emiten melalui laporan keuangan (Darmadji \& Hendy, 2006). Perusahaan akan menyajikan berbagai rasio terkait kinerja perusahaannya, dengan demikian calon pemegang saham dapat menganalisis perusahaan melalui rasio-rasio tersebut, seperti melakukan perbandingan rasio antar perusahaan sejenis mana yang lebih baik. Dengan bantuan laporan keuangan perushaaan ini, dapat memudahkan dan mempercepat investor dalam mengambil keputusan investasi (Fahmi, 2006).

Dalam jual beli saham di pasar modal, pelepasan saham pertama dinamakan Initial Public Offering (IPO). Harga saham pertama yang ditawarkan oleh perusahaan dalam IPO merupakan harga saham terendah, penawaran umum ini ini dilepas agar publik atau masyarakat dapat membeli saham tersebut. Perusahaan yang dapat melakukan IPO adalah perusahaan publik yang sudah terdaftar di bursa efek. Dalam perkembangannya investasi yang dilakukan oleh para investor tidak selalu mendapatkan keuntungan untuk itu ada beberapa hal yang harus diperhatikan oleh para investor.

Masalah yang harus diperhatikan dalam berinvestasi khususnya investasi saham salah satunya adalah bagaimana perusahaan tersebut dapat selalu menaikkan harga sahamnya, karena jika harga saham perusahaan secara terus-menerus mengalami kenaikan membuktikan bahwa perusahaan mengalami kemajuan. Dalam kenyataannya perusahaan yang memiliki prospek yang baik misalnya penggunaan utang dalam perusahaan tersebut relatif kecil, namun harga yang terjadi dari periode keperiode selalu mengalami penurunan, hal tersebut dapat menyebabkan 
para investor berpikir dua kali untuk investasi di perusahaan tersebut. Oleh karena itu salah satu faktor yang harus diperhatikan dalam berinvestasi adalah bagaimana perusahaan dapat menaikkan harga sahamnya. Karena dengan harga yang selalu naik investor akan mendapatkan capital gain yang lebih.

Maka dari itu, artikel ini bertujuan untuk menganalisis pengaruh rasio profitabilitas yang direpresentasikan oleh Return On Assets (ROA) dan Return On Equity (ROE) kemudian rasio solvabilitas yang diwakili oleh Debt to Equity Ratio (DER) sebagai variabel yang diduga memiliki pengaruh terhadap harga saham PT. Wijaya Karya, Tbk. dan PT. Aneka Tambang, Tbk. yang terdaftar di Jakarta Islamic Index (JII) pada periode 2016-2018. Penelitian-penelitian sebelumnya masih memiliki inkonsistensi terkait pengaruh variabel-variabel tersebut, seperti penelitian dari dengan demikian dapat dilihat gap pada penelitian ini sehingga perlu dilakukan analisis kembali.

\section{Metode}

Artikel ini menyajian data penelitian dengan metode deskriptif dan pendekatan kuantitatif. Penelitian kuantitatif ini menjelaskan hubungan antara variable bebas dengan variable terikat. Objek dalam penelitian ini menggunakan populasi yang terdiri dari 30 perusahaan yang terdaftar di JII. Sedangkan sampel dipilih dengan metode purposive sampling, yaitu suatu teknik pemilihan sampel dengan sengaja dimana peneliti dengan sengaja telah memiliki karakteristik sampel yang akan dipilih. Dalam penelitian ini karakteristik sampel yang dibutuhkan ialah, perusahaan yang terdaftar di JII selama tahun 2016-2018, memiliki laporan keuangan lengkap selama periode tersebut, perusahaan yang berada disektor tambang logam dan sektor kontruksi bangunan. Maka berdasarkan karakteristik sampel tersebut, peneliti mendapatkan sampel dua perusahaan yaitu PT. Aneka Tambang, Tbk. dan PT. Wijaya Karya, Tbk. dengan demikian, data penelitian ini merupakan data sekunder yang berasal dari laporan keuangan tahunan yang telah dipublikasikan dalam website resmi masing-masing perusahaan. untuk mendapatkan hasil penelitian, penelitian ini menggunakan teknik analisis data regresi berganda dan diolah dengan bantuan software SPSS.

\section{Hasil dan Pembahasan \\ Hasil Penelitian}

Analisis data pada penelitian ini menggunakan analisis regresi linear berganda, dimana tujuannya untuk mengetahui pengaruh variabel independen terhadap variabel dependen baik secara parsial maupun simultan. Berikut hasil analisis regresi linear berganda:

\section{Tabel 1 Hasil Uji Regresi Berganda \\ Coefficients $^{a}$}

\begin{tabular}{|c|c|c|c|c|c|c|}
\hline \multirow{2}{*}{ Model } & \multicolumn{2}{|c|}{ Unstandardized Coefficients } & Standardized Coefficients & \multirow{2}{*}{$\mathrm{T}$} & Sig. \\
\cline { 2 - 6 } & $\mathrm{B}$ & Std. Error & Beta & & \\
\hline \multirow{3}{*}{1} & (Constant) & 1178.879 & 1623.166 & & .726 & .543 \\
\cline { 2 - 6 } & Return On Asset & -435.956 & 1754.059 & -1.015 & -.249 & .827 \\
\cline { 2 - 6 } Return On Equity & 378.752 & 847.347 & 2.840 & .447 & .699 \\
\cline { 2 - 6 } & Debt to Equity Ratio & -9.263 & 22.455 & -1.127 & -.413 & .720 \\
\hline
\end{tabular}

a. Dependent Variable: Harga Saham

Sumber: hasil output SPSS versi 16 
Merujuk pada hasil statistik menggunakan SPSS dengan Y adalah harga saham, kemudian $\mathrm{X}_{1}$ ialah ROA, $\mathrm{X}_{2}$ merupakan $\mathrm{ROE}$, dan $\mathrm{X}_{3}$ adalah $\mathrm{DER}$, maka persamaan regresi linear berganda yang didapatkan adalah :

$$
Y=1178.879-435.956 X_{1}+378.752 X_{2}-9.263 X_{3}+e .
$$

Mengacu pada persamaan regresi berganda tersebut, diperoleh hasil yaitu, nilai konstanta (a) yaitu 1178,879. Angka tersebut berarti bahwa jika nilai Return On Assets (ROA), Return On Equity (ROE) dan Debt to Equity Ratio (DER) adalah tetap atau konstan, maka harga saham PT. Wijaya Karya, Tbk. dan PT. Aneka Tambang, Tbk. akan bernilai 1178,879.

Kemudian nilai koefisien regresi $b_{1}$ yaitu -435,956. Nilai tersebut diperoleh hasil negatif, artinya jika Return On Assets (ROA) mengalami penurunan satu persen dengan asumsi variabel lain bernilai tetap, maka harga saham akan mengalami kenaikan sebesar 435,956.

Selanjutnya, variabel Return On Equity (ROE) memiliki nilai koefisien regresi sebesar 378,752. Angka tersebut bernilai positif, artinya jika Return On Equity (ROE) mengalami peningkatan sebesar satu persen dengan asumsi variabel lainnya kontans, maka harga saham pun akan mengalami kenaikan sebesar 378,752.

Terakhir, variabel Debt to Equity Ratio (DER) memiliki pengaruh negatif dengan koefisien regresi sebesar 9,263. Hal ini menunjukkan, apabila Debt to Equity Ratio mengalami penurunan sebesar satu persen dengan asumsi variabel ROA dan ROE tetap, maka harga saham akan mengalami kenaikan sebesar 9,263.

\section{Uji Hipotesis}

Berdasarkan tabel 1 diperoleh hasil uji hipotesis parsial yang ditunjukkan oleh hasil t-tes:

a. Uji $t$

Uji $t$ bertujuan untuk melihat pengaruh variabel independen terhadap dependen secara parsial. Mengacu pada hasil regresi berganda di atas, diperoleh nilai t-statistic yaitu sebagai berikut:

Hasil t-test yang pertama yaitu pengaruh Return On Assets (ROA) terhadap harga saham PT. Aneka Tambang, Tbk. dan PT. Wijaya Karya, Tbk. berdasarkan pada tabel tersebut diperoleh $t$ test -0,249 dengan taraf signifikansi 0,872. Hasil ini menunjukkan bahwa nilai signfikansi tidak memenuhi kriteria berpengaruh dimana harus lebih kecil dari 0,05. Pada penelitian ini 0,872 > 0,05, sehingga diperoleh bahwa Return On Assets (ROA) tidak berpengaruh signifikan terhadap PT. Aneka Tambang, Tbk. dan PT. Wijaya Karya, Tbk. periode 2016-2018.

Hasil t-test yang kedua menunjukkan pengaruh Return On Equity (ROE) terhadap harga saham PT. Aneka Tambang, Tbk. dan PT. Wijaya Karya, Tbk. berdasarkan pada tabel tersebut diperoleh 0,447 dengan signifikansi 0,699. Hasil ini menunjukkan bahwa nilai signfikansi tidak memenuhi kriteria berpengaruh dimana harus lebih kecil dari 0,05. Pada penelitian ini 0,699 > 0,05, sehingga diperoleh bahwa Return On Equity (ROE) tidak berpengaruh signifikan terhadap PT. Aneka Tambang, Tbk. dan PT. Wijaya Karya, Tbk. periode 2016-2018.

Hasil t-test yang ketiga untuk melihat pengaruh Debt to Equity Ratio (DER) terhadap harga saham PT. Aneka Tambang, Tbk. dan PT. Wijaya Karya, Tbk. berdasarkan pada tabel tersebut diperoleh -0,413 dengan signifikansi 0,720. Hasil ini menunjukkan bahwa nilai signfikansi tidak memenuhi kriteria berpengaruh dimana harus lebih kecil dari 0,05. Pada penelitian ini 0,720 > 0,05, sehingga diperoleh bahwa Debt to Equity Ratio (DER) tidak berpengaruh signifikan terhadap PT. Aneka Tambang, Tbk. dan PT. Wijaya Karya, Tbk. periode 2016-2018.

b. Uji F 
Uji F dilakukan untuk melihat pengaruh secara simultan variabel ROA, ROE, dan DER terhadap Harga Saham. Hasil uji F didapatkan dari perhitungan statistik menggunakan software SPSS, dan dilihat dari tabel Anova. Maka hasil dari uji F, adalah sebagai berikut:

Tabel 2 Hasil Uji F Pengaruh ROA, ROE, dan DER terhadap Harga Saham ANOVA $^{b}$

\begin{tabular}{|l|c|c|c|c|c|}
\hline Model & Sum of Squares & Df & Mean Square & F & Sig. \\
\hline 1 Regression & 1645179.601 & 3 & 548393.200 & 1.916 & $.361^{\mathrm{a}}$ \\
Residual & 572403.732 & 2 & 286201.866 & & \\
Total & 2217583.333 & 5 & & & \\
\hline
\end{tabular}

a. Predictors: (Constant), Debt to Equity Ratio, Return On Asset, Return On Equity

b. Dependent Variable: Harga Saham

Sumber: hasil output SPSS versi 16

Mengacu pada hasil uji statistik yang tertera pada tabel 2, diperoleh hasil F-statistic 1,916 dengan Signifikansi 0,361 yang mana signifikansi lebih besar dari 0,05. Dengan demikian diperoleh hasil bahwa ROA, ROE, dan DER secara simultan tidak berpengaruh signifikan terhadap harga saham PT. Aneka Tambang, Tbk. dan PT. Wijaya Karya, Tbk. periode 20162018.

\section{Analisis Koefisien Determinasi}

Uji koefisien determinasi digunakan untuk mengukur seberapa besar kemampuan variabelvariabel independen dalam model penelitian ini mampu menjelaskan kontribusi pengaruhnya terhadap variabel dependen. Ketentuan pengambilan keputusannya dengan melihat nilai $\mathrm{R}$ Square atau yang lebih relevan adalah Adjusted R Square, dimana semakin mendekati angka 1 berarti variabel-variabel independen memiliki pengaruh yang besar dalam menerangkan variabel dependen. Berikut ini adalah hasil uji koefisien determinasi:

Tabel 4.12

\section{Hasil Uji Koefisisen Determinasi}

Model Summary ${ }^{b}$

\begin{tabular}{|c|c|c|c|c|}
\hline Model & $\mathrm{R}$ & $\mathrm{R}$ Square & Adjusted R Square & Std. Error of the Estimate \\
\hline 1 & $.861^{\mathrm{a}}$ & .742 & .355 & 534.978 \\
\hline
\end{tabular}

a. Predictors: (Constant), Debt to Equity Ratio, Return On Asset, Return On Equity

b. Dependen Variable : Harga Saham

Sumber :Data sekunder diolab oleh SPSS 16.0

Mengacu pada hasil yang tertera di tabel, diperoleh nilai Adjusted R Square adalah 0,355 atau 35,5\%. Hal ini menunjukkan kemampuan variabel bebas atau independen dalam menjelaskan variabel terikat adalah sebesar 35,5\% sisanya 64,5\% dijelaskan oleh variabel lain yang tidak dijelaskan dalam penelitian ini. Dengan demikian, hasil ini memberikan gambaran bahwa secara perhitungan statistik variabel ROA, ROE, dan DER mampu memberikan efek terhadap fluktuasi harga saham PT Wijaya Karya Tbk dan PT Aneka Tambang Tbk hanya sebesar 35,5\%. 


\section{Pembahasan Hasil Penelitian}

\subsection{Analisis Pengaruh Return On Assets terhadap Harga Saham PT Wijaya Karya Tbk. dan PT Aneka Tambang Tbk. periode 2016-2018}

Return On Asset (ROA) merupakan rasio profitabilitas yang menggambarkan efektivitas perusahaan dalam menghasilkan keuntungan dari pemanfaatan optimal aset yang dimilikinya. Secara teori, tingginya perolehan ROA suatu perusahaan menunjukkan efisiensi yang tinggi pula dari penggunaan aset atau aktiva perusahaan untuk menghasilkan laba. Dengan demikian, laba yang besar akan menarik investor untuk membeli saham perusahaan sehingga harga saham akan meningkat.

Munawir (2012) berpendapar bahwa Return on Aset (ROA) diperoleh dengan membandingkan laba sebelum pajak selama periode akuntansi dengan rata-rata volume usaha atau aset. Fluktuasi nilai ROA akan mengganggu perusahaan, sehingga perusahaan harus memperhatikan beberapa faktor yang menyababkan fluktuasi nilai ROA tersebut, seperti penggunaan aset yang optimal sehingga menambah pendapatan operasional yang menunjang laba, peralihan portofolio perusahaan ke dalam beberapa bentuk aset yang berharga sehingga menambah pendapatan, peningkatan pendapatan bunga yang tinggi, penggunaan aset tidak produktif dimaksimalkan (Novita K \& Onoyi, 2016).

Namun hasil penelitian ini tidak sejalan dengan teori di atas, dimana ROA pada kedua perusahaan ini tidak berpengaruh signifikan dalam fluktuasi harga saham PT Wijaya Karya Tbk dan PT Aneka Tambang Tbk. dimana diperoleh hasil signifikansi 0,827 >0,05. Selain itu, dari hasil regresi ROA memiliki pengaruh negatif terhadap harga saham, artinya peningkatan ROA justru menurunkan harga saham dan penurunan ROA akan menaikkan harga saham.

Menurut analisis peneliti, tidak berpengaruhnya ROA ini karena ROA tidak langsung memiliki pengaruh terhadap deviden atau capital gain yang akan diperoleh perusahaan. Investor hanya akan mempedulikan perolehan laba bersih yang real seperti rasio Net Profit Margin, dan Earning Per Share (EPS) perusahaan. Kemudian, ROA negatif menunjukan bahwa total aktiva yang dipergunakan tidak memberikan keuntungan bagi perusahaan atau rugi. Efisiensi penggunaan aktiva tidak meyakinkan investor dalam menentukan perolehan laba, sehingga investor tidak memperhatikan rasio ini.

Penelitian ini konsisten dengan hasil penelitian yang dilakukan oleh Hanum (2011) di mana $R O A$ (Return On Assets) tidak memiliki hubungan yang signifikan terhadap harga saham. Namun bertolak belakang dengan penelitian yang dilakukan oleh Setyorini (2016) dan Anderson (2015) yang mana ROA memiliki pengaruh yang signifikan terhadap harga saham, namun pada penelitian Setyorini ROA memiliki pengaruh negatif sedangkan pada penelitian Anderson (2015) ROA memiliki pengaruh positif terhadap harga sahm.

\subsection{Analisis Pengaruh Return On Equity terhadap Harga Saham PT Wijaya Karya Tbk. dan PT Aneka Tambang Tbk. periode 2016-2018}

ROE adalah satu rasio keuangan yang digunakan oleh investor maupun perusahaan untuk melihat seberapa besar kemampuan modal untuk menghasilkan keuntungan atau laba bersih. Dalam teorinya, ketika nilai ROE meningkat maka investor akan tertarik berinvestasi dan berspekulasi bahwa kinerja perusahaan tersebut baik sehingga dapat menjamin tingkat 
pengembalian investasi dan pada akhirnya harga saham pun akan ikut tinggi (Roni \& Pangestu, 2020). Semakin tinggi nilai ROE ini akan menggambarkan pada pengguna laporan keuangan khususnya investor bahwa perusahaan mampu mengelola modal yang ada dengan baik, sehingga peluang untuk pengembalian modal tersebu tinggi dan berdampak pada harga saham.

Namun hasil penelitian ini tidak sejalan dengan teori di atas, dimana ROE pada kedua perusahaan ini tidak berpengaruh signifikan dalam fluktuasi harga saham PT Wijaya Karya Tbk dan PT Aneka Tambang Tbk. dimana diperoleh hasil signifikansi 0,699>0,05. Selain itu, dari hasil regresi ROE memiliki pengaruh positif terhadap harga saham, artinya peningkatan ROE akan memberikan efek baik pada harga saham.

Sama halnya dengan ROA, dimana ROE tidak begitu memiliki hubungan langsung terhadap dividen, EPS, dan laba perusahaan. ROE hanya menggambarkan penggunaan optimal dari modal yang ada di perusahaan, sehingga menurut hasil peneliti ROE ini tidak begitu menjamin bagi investor. Menurut analisis peneliti, tidak sejalannya hasil penelitian ini dengan teori dan beberapa penelitian terdahulu adalah investor cenderung lebih fokus pada kebijakan deviden dan laba ditahan yang dikeluarkan oleh perusahaan. Oleh karena, gambarang ROE tidak mampu memberikan ketertarikan investor untuk membeli saham sehingga ROE tidak memiliki pengaruh terhadap harga saham PT. Wijaya Karya, Tbk. dan PT. Aneka Tambang, Tbk.

Sehingga penelitian ini memiliki kesamaan dengan hasil penelitian yang dilakukan oleh Pasaribu (2012), dimana harga saham juga tidak dipengaruhi oleh Return On Equity. Namun penelitian ini bertolak belakang dengan penelitian yang dilakukan oleh Hutami (2012) bahwa ROE memberikan efek positif terhadap harga saham dan pengaruhnya signifikan dalam perubahan harga saham. Juga memiliki inkonsistensi dengan penelitian Setyorini (2016) namun pengaruh yang didapatkan olehnya adalah negatif terhadap harga saham walaupun hubungannya signifikan.

\subsection{Pengaruh Pengetahuan Debt to Equity Ratio terhadap Harga Saham PT Wijaya Karya Tbk. dan PT Aneka Tambang Tbk. periode 2016-2018}

Menurut sawir Debt to Equity Ratio (DER) adalah rasio yang menggambarkan perbandingan utang dan ekuitas dalam pendanaan perusahaan dan menunjukan kemampuan modal sendiri perusahaan modal sendiri perusahaan tersebut untuk memenuhi seluruh kewajibannya (Sawir, 2003). Debt to Equity Ratio (DER) ini merupakan rasio leverage dan menjadi salah satu faktor yang dipertimbangkan oleh investor ketika akan berinvestasi. Debt to Equity Ratio (DER) adalah rasio yang membandingkan antara total kewajiban dengan total ekuitas yang dimiliki perusahaan dimiliki oleh perusahaan dibandingkan dengan hutang yang dimiliki, maka rasio debt to equity nya semakin kecil (Juniarti \& Sentosa, 2009).

Namun hasil penelitian ini tidak sejalan dengan teori di atas, dimana Debt to Equity Ratio (DER) pada kedua perusahaan ini tidak berpengaruh signifikan dalam fluktuasi harga saham PT Wijaya Karya Tbk dan PT Aneka Tambang Tbk. dimana diperoleh hasil signifikansi 0,720 > 0,05. Selain itu, dari hasil regresi Debt to Equity Ratio (DER) memiliki pengaruh negatif terhadap harga saham, artinya peningkatan Debt to Equity Ratio (DER) akan memberikan efek baik pada harga saham. Karena tingkat hutang yang tinggi akan memberikan sinyal buruk bagi investor untuk berinvestasi. Selain itu, DER yang tinggi akan memberikan risiko yang tinggi bagi 
perusahaan dan investor akan menilai kemungkinan return saham yang rendah sehingga berdampak pada harga saham yang akan turun karena rendahnya daya beli saham tersebut.

Penelitian ini sejalan dengan penelitian yang dilakukan oleh Wicaksono (2015) dan Nurfadilah (2011) dimana memperoleh hasil DER tidak memiliki pengaruh terhadap harga saham. Namun tidak sejalan dengan penelitian yang dilakukan oleh Anderson (2015) dan Febianto (2015) dimana DER memiliki pengaruh signifikan terhadap harga saham.

\section{Kesimpulan}

Hasil penelitian dan pembahasan di atas menunjukkan bahwa Return On Asset (ROA), Return On Equity (ROE), dan Debt to Equity Ratio (DER) baik secara parsial dan simultan tidak memiliki pengaruh yang signifikan terhadap harga saham PT. Wijaya Karya, Tbk. dan PT. Aneka Tambang, Tbk. periode 2016-2018. Selain itu, pengaruhnya secara bersama-sama dari hasil uji koefisien determinasi hanya 35,7\%, artinya hanya 35,5\% ROA, ROE, dan DER memiliki pengaruh terhadap harga saham, sedangkan sisanya $64,5 \%$ dipengaruhi oleh faktor lain di luar penelitian ini.

Mengacu pada hasil ini, dapat dilihat bahwa harga saham PT. PT. Wijaya Karya, Tbk. dan PT. Aneka Tambang, Tbk. tidak dipengaruhi fluktuasinya oleh ROA, ROE, dan DER. Investor mempedulikan faktor lain diluar faktor ROA, ROE, dan DER untuk membeli saham kedua perusahaan tersebut, seperti Dividen Payout Ratio (DER), Earning Per Share (PER), Net Profit Margin (NPM), dan lain sebagainya. Oleh karena itu, peneliti menyarankan untuk memperhatikan faktor-faktor lain tersebut agar dapat menarik investor lebih banyak.

\section{Referensi}

Anderson, M. (2015). Pengaruh Corporate Social Responsibility Terhadap Respon Investor pada Perusahaan Non Kapitalisasi Besar (Non-Big Capitalization) di Indonesia. Business Accounting Review 03 (1), 316-326.

Darmadji, T., \& Hendy, M. F. (2006). Pasar Modal di Indonesia Pendekatan Tanya Jawab. Jakarta: Salemba Empat.

Fahmi, I. (2006). Analisis Investasi dalam Perspektif Ekonomi dan Politik. Bandung : Refika Aditama. Fahmi, I. (2015). Pengantar Manajemen Keuangan. Bandung: Alfabeta.

Febianto, A. (2015). Pengaruh Return On Asset, Current Ratio, Debt to Equity Ratio, Dividen, Laba Bersih, Dan Dividend Payout Ratio Terhadap Harga Saham Pada Perusahaan Yang Terdaftar Di Jakarta Islamic Index Periode 2009-2014. Jurnal Ekonomi Syari'ah 02 (1), 34-46.

Hanum, Z. (2011). Pengaruh Return On Asset (ROA), Return On Equity (ROE), dan Earning Per Share (EPS) terhadap Harga Saham pada Perusahaan Otomotif yang Terdaftar Di Bursa Efek Indonesia Periode 2008-2011. Jurnal Manajemen dan Bisnis, 08 (2).

Hutami, R. P. (2012). Pengaruh Dividend Per Share, Return On Equity, dan Net Profit Margin terhadap Harga Saham Perusahaan Industri Manufaktur yang Tercatat di Bursa Efek Indoesia Periode 2006 - 2010. Jurnal Nominal 01 (1), 104-123.

Juniarti, \& Sentosa, A. A. (2009). Pengaruh Good Corporate Governance, Voluntary Disclosure terhadap Biaya Hutang (Costs of Debt). Jurnal Akuntansi dan Kenangan (FE Universitas Kristen Petra) 11 (02), 88-100.

Munawir. (2012). Analisis Laporan Kenangan. Yogyakarta: Liberty. 
Novita K, F., \& Onoyi, N. J. (2016). Pengaruh Loan To Deposit Ratio (Ldr), Capital Adequacy Ratio (Car), Dan Return On Assets (Roa) Terhadap Harga Saham Pada Perusahaan Perbankan Yang Terdaftar Dibursa Efek Indonesia (Bei) Tahun 2009-2013. Jurnal Ilmiah Zona Akuntansi, Volume 6 Nomor 3, 71-80.

Nurfadilah, M. (2011). Analisis Pengaruh Earnings Per Share, Debt to Equity Ratio, dan Return On Equity Terhadap Harga Saham PT. Unilever, Tbk. Jurnal Manajemen dan Akuntansi 12 (1), 45-50.

Pasaribu, R. (2012). Pengaruh Variabel Fundamental Terhadap Harga Saham Perusahaan Go Public Di Bursa Efek Indonesia (BEI) Periode 2003-2006. Jurnal Ekonomi dan Bisnis 02 (2), 101-113.

Roni, \& Pangestu, D. (2020). Pengaruh ROE dan EPS terhadap Harga Saham . Journal of Accounting and Finance (JACFIN), 1 (1), 30-36.

Sawir, A. (2003). Analisis Kinerja Keuangan dan Perencanaan Kenangan Perusabaan . Jakarta: Gramedia Pustaka Utama.

Setyorini. (2016). Pengaruh Return On Asset (ROA), Return On Equity (ROE),dan Earning Per Share (EPS) Terhadap Harga Saham Perusahaan Real Estate di Bursa Efek Indonesia (Studi Kasus Pada 20 Perusahaan 20 Perusahaan Periode 2011-2015). Journal Of Management 02 (2). 